\title{
Aggressive and Predatory Pricing: Insights and Empirical Examination in the Airline Industry
}

\author{
Ashutosh Dixit, Gregory T. Gundlach, Naresh K. Malhotra, \\ and Fred C. Allvine
}

\begin{abstract}
The authors advance the understanding of predatory pricing through an examination of the Supreme Court's elements for proving allegations of such conduct in the marketplace. On the basis of recent research in economics, marketing, and other fields and a 2001 U.S. Department of Transportation report, the authors offer several insights into understanding and applying these elements in the airline industry. Drawing on these insights, the authors conduct empirical research to examine patterns of market power on the part of major airlines in selected hub airports and the pricing response to the entry of discount airlines over time on the part of a major airline. They also examine the relationship between market power and pricing-related conduct through a simultaneous equation model. Findings from these analyses yield insights into understanding aggressive and predatory pricing in the airline industry.
\end{abstract}

$\mathbf{P}$ rice, or the consideration asked for in an exchange, is a central concept in both economics and marketing. In relation to competitive strategy, deep price cuts and other pricing-related conduct that reflects a significant departure from competitive norms are often motivated by a firm's desire to enhance its own performance. When such conduct is intended to impair a rival's performance or competitive viability significantly, it may be termed "aggressive" (Guiltinan and Gundlach 1996). If the conduct leads to a substantial reduction in competition that undermines consumer welfare, it may be considered "predatory" and potentially cognizable under antitrust laws (Bolton, Brodley, and Riordan 2000).

The Supreme Court has defined predatory pricing as "pricing below an appropriate measure of cost for the purpose of eliminating competitors in the short run and reducing competition in the long run" (Cargill Inc. v. Monfort of Colorado Inc. 1986, p. 117). Because the very mechanism by which a firm engages in predatory pricing is often the same mechanism by which it stimulates competition (e.g., cutting prices to increase business represents a key element of competition), courts, including the Supreme Court, have been circumspect in their assessments of predatory pricing

Ashutosh Dixit is Assistant Professor of Marketing, James J. Nance College of Business, Cleveland State University (e-mail: a.dixit1@ csuohio.edu). Gregory T. Gundlach is Visiting Eminent Scholar of Wholesaling and Professor of Marketing, Coggin College of Business, University of North Florida (e-mail: ggundlac@unf.edu). Naresh K. Malhotra is Regents Professor of Marketing (e-mail: naresh. malhotra@mgt.gatech.edu), and Fred C. Allvine is Professor of Marketing (e-mail: fred.allvine@mgt.gatech.edu), College of Management, Georgia Institute of Technology. The first author acknowledges the Terry Sanford Award and the Coca-Cola Center for Marketing Research Award from the University of Georgia for this research. allegations. Reflecting on the implications of incorrect adjudications involving predatory pricing, in Matsushita Electric Industrial Company v. Zenith Radio Corporation (1986, p. 594), the Supreme Court noted, "Mistaken inferences ... are especially costly because they chill the very conduct the antitrust laws are designed to protect."

Circumspection on the part of the courts also has been bolstered by judicial reliance on the behavioral assumptions of neoclassical price theory for understanding such conduct. ${ }^{1}$ This body of thought envisions business behavior to be motivated exclusively by profit maximization, in which parties possess perfect information and make decisions in a rational, calculated way. Given these assumptions and by an extension of the logic that predatory pricing to maximize profits is considered irrational, the Supreme Court's oftencited view has been that predatory pricing is "rarely tried and even more rarely successful" (Matsushita Electric Industrial Company v. Zenith Radio Corporation 1986, p. 589). ${ }^{2}$

Driven by the potential costs to competition of mistaken inferences and the perceived rarity of predatory pricing in practice, in 1993 the Supreme Court established several ele-

1For a detailed discussion of these assumptions and theory, see Bork (1978), Gellhorn (1975), Mansfield (1982), McCloskey (1985), and Stigler (1966).

2Theoretically based skepticism of predatory pricing extends from the presumed irrationality of a firm engaging in predatory pricing to maximize profits. If a perfectly competitive environment is assumed, a firm engaging in such conduct would incur such severe short-term losses in its attempt to disadvantage rivals that it would not rationally consider such a strategy. Even if the firm were to engage in such conduct and successfully eliminate rivals, to be profitable, the predatory firm would need to recover losses by subsequently raising prices to supracompetitive (i.e., above normal competitive) levels. In an environment of complete information, prices at such levels would attract new competitors that hope to obtain surplus profits and thus would reduce the chances of the predatory firm recouping its losses. Realizing this, the firm would calculate the probability of recovering lost profits to be low and, in turn, avoid such conduct. 
ments in law for proving allegations of such conduct. In Brooke Group Ltd. v. Brown Williamson Tobacco Corp. (1993, pp. 4702-4703), the Court noted,

First, a plaintiff ... must prove that the prices complained of are below an appropriate measure of its rival's costs,... [and] second,... [there must be a] demonstration that the competitor has a reasonable prospect [under Robinson-Patman], or under Section 2 of the Sherman Act, a dangerous probability, of recouping its investment in below-cost prices.

According to the Court (and others that have come to similar conclusions), consideration must be given to an alleged predator's "market power," "predatory conduct," and the "prospect of recoupment." With respect to market power, because allegations of predatory pricing are generally brought forth on the basis of the prohibitions contained in the Sherman Antitrust Act (1890; or the RobinsonPatman Act [1936]), depending on the specific allegation (e.g., monopolization or attempt to monopolize), an alleged predator must be shown to possess a sufficient amount of market power in a defined market and to be in a position to engage in below-cost pricing in ways that permit it to exclude competition, raise prices, and subsequently recover lost profits through recoupment. For predatory conduct, although specifying that the prices in question must be below an appropriate measure of its rivals' costs, the Supreme Court declined (and has repeatedly declined) to state what measure of cost should be applied. ${ }^{3}$ With some variation, the measure applied most often in the federal courts has been a price that is below average variable cost. Finally, for recoupment, the likelihood must exist that the alleged predator's below-cost pricing will drive the intended target from the market and that, given relevant considerations (i.e., market shares, ease of entry, excess capacity, and all other pertinent factors), the market is susceptible to monopoly pricing following the victim's exit. When a firm with sufficient market power in a defined market engages in below-cost pricing and when a dangerous (or reasonable) probability of recoupment exists in the ways described, the welfare effects of such conduct may be found to be anticompetitive. 4

Together, the considerable requirements for proving allegations of predatory pricing mandated by the Supreme Court in Brooke Group Ltd. v. Brown Williamson Tobacco Corp. (1993), the assumptions and theory on which they are grounded, and the summary disposition of several subsequent federal cases involving predatory pricing have lead some scholars (e.g., Zerbe and Mumford 1996) to voice concerns about the current legal standard for predatory pricing. As Adams and Brock (1996, p. 868) observe,

The problem [of predatory pricing] cannot be meaningfully captured or evaluated on the basis of simplistic rules of thumb

\footnotetext{
${ }^{3}$ According to the Court in Brooke Group Ltd. v. Brown Williamson Tobacco Corp. (1993, p. 21), "As a general rule, the exclusionary effect of prices above a relevant measure of cost either reflects the lower cost structure of the alleged predator, and so represents competition on merits, or it is beyond the practical ability of the judicial tribunal to control without countering intolerable risks of chilling legitimate price-cutting" (see also Areeda and Turner 1975).

${ }^{4}$ For a recent discussion of predatory pricing analysis, see Adams and Brock (1996), Gifford (1994), Shores (1995), and Zerbe and Mumford (1996, n. 3).
}

premised on the assumption that the practice does not occur. Such rules provide a shortcut to a predetermined conclusion rather than an economically sound path for reaching an opinion.

Concerns about the legal standard, as well as emerging insights and understanding developed in economics, marketing, and other fields, have prompted inquiry and newer thinking about predatory pricing. In general, this thinking posits that the previous foundations on which the current legal standard rests may be based largely on theoretical constructs and assumptions that are not sufficiently inclusive of the realities of a marketplace in which oligopolistic structures, incomplete information, and strategic behavior are commonplace (see Bolton, Brodley, and Riordan 2000; Grewal and Compeau 1999; Hawker 1996; Sullivan and Grimes 2000). Drawing on industrial organization theory in economics, which relaxes the perfect information and static assumptions of neoclassical price theory but still regards managers as profit maximizers, and applying gametheoretic interpretations of strategic behavior, this newer thinking implies that predation may occur because of the lack of perfect information and the dynamic interplay of the market. Added understanding from marketing and other fields, which further relaxes the assumptions of economic theory in ways that reveal how predatory pricing may be both rational and profitable for a firm intent on engaging in such conduct, bolsters this thinking.

Against the backdrop of judicial sentiments that predatory pricing is "rarely tried and even more rarely successful," this newer thinking has prompted inquiries of predatory pricing by researchers and other public policy institutions. For example, in relation to predatory conduct, Edlin (2002, p. 943) observes that "[p]rice below average variable cost may be a sufficient, but not necessary condition for predatory pricing." Recent studies also provide a more expansive critique of market power (e.g., Guiltinan and Gundlach 1996; Kate and Neils 2002) and the recoupment standard (e.g., Hemphill 2001). Among research by public policy institutions, the U.S. Department of Transportation (2001; hereinafter, DOT) has responded to complaints by investigating whether incumbent airlines responded to entry by other airlines in ways that seemed to be intended not as legitimate competition but rather as a means to create or maintain market power through predatory conduct (see the Appendix). On the basis of a broad-based investigation, the DOT (2001, p. 1, emphasis added) found,

Some of the responses by the incumbent airlines to the entry of a new discount airline in a market are difficult to reconcile as competitive.... [I]ncumbent airlines at times have responded to new competition with fare cuts, capacity increases, and other practices that are apparently designed to reduce or eliminate competition. An airline's success in eliminating or reducing competition will harm the public by denying travelers the lower fares and better service created through competition.

In conducting its investigation, the DOT applied insights from more recent thinking about predatory pricing. Drawing on this thinking and other considerations, it proposed a "profit-maximization response standard" for assessing predatory conduct in the airline industry. This standard calls for inquiry into the pattern of pricing conduct and capacity or volume expansion on the part of an airline in possession of market power and alleged to have engaged in predation. 
Prompted by the DOT's (2001) findings and drawing on recent insights from economics, marketing, and other disciplines, we examine the legal elements required by the Supreme Court for proving predatory pricing (i.e., market power, predatory conduct, and recoupment) in the context of the airline industry. In particular, we extend the understanding of market power within the airline industry through an examination of its domain, its symmetry, and the role of barriers to entry in facilitating its possession. Furthermore, we provide insights into understanding predatory conduct in the airline industry through consideration of the DOT's profitmaximizing response standard and its conception of the role of capacity expansion (e.g., volume) for understanding such conduct. We also address aspects of recoupment as it relates to price cuts and manager decision making. Then, we empirically examine patterns of market power in the airline industry and the pricing conduct of a major airline to the entry and subsequent exit of discount airlines in its markets to discern whether such market power and conduct at least allows for the possibility of aggressive and predatory pricing as contemplated by the Supreme Court. To explicate the complex relationships between the major airline's market power and predatory conduct as called for by the DOT's profit-maximizing response standard, we also develop and test a simultaneous equation model that includes conduct, as measured through both price cuts and volume expansion. On the basis of our conceptual and empirical findings, we discuss various policy implications and avenues for further research.

\section{Background: Developments in the U.S. Airline Industry}

The U.S. airline industry was deregulated in 1978 with the belief that "[u]nleashing the forces of competition will bring air travel within reach of people of limited means" (Kahn 2000 , p. 4). However, following deregulation, the major airlines converted their operations to "hub-and-spoke" systems. During this time, repeated entry attempts by new or smaller expanding airlines had been reported to have provoked fierce price wars; in almost all cases, the entrant exited or was confined to a niche market (Levine 1991). By the end of the 1980s, almost all the discount airlines that started after deregulation had gone out of business. In the mid-1990s, other discount airlines tried to penetrate the concentrated, high-priced hub markets of the major airlines (e.g., Atlanta, Chicago, Dallas) but were met with aggressive responses and, in certain cases, exited the markets. Only a few of these new entrant airlines of the 1990s survive today, and there have been few new entries in the industry from 1989 to 2000 (Oster and Strong 2001; Transportation Research Board 1999).

During this latter period, new entrant airlines made several complaints of aggressive reactions by major airlines, which led to a DOT (2001) investigation. The DOT's "[i]nvestigation suggested that some of the low-fare airlines' complaints about unfair and exclusionary conduct were valid" (p. 6) and that "[n]ew service by a low fare airline is therefore likely to be the only way that many hub markets will ever benefit from competitive airline service" (p. 31). An important finding of the DOT investigation was that some pricing practices in the airline industry could not be reconciled as fair and thus could be construed as aggressive and exclusionary of competition given certain circumstances. ${ }^{5}$

\section{Insights for Understanding Aggressive and Predatory Pricing in the Airline Industry}

Against the backdrop of the Supreme Court's elements for proving allegations of predatory pricing and in the wake of the DOT's (2001) report and newer thinking about predatory pricing, in this section we examine and advance several insights into understanding predatory pricing in the airline industry. These insights add to the growing body of thought aimed at understanding and assessing the nature and effects of predatory pricing for competition and consumers.

\section{Market Power}

The Supreme Court and applicable literature define market power (also termed "monopoly" power) as "the power to control market prices or exclude competition" (U.S. v. E.I. DuPont de Nemours \& Co. 1956, p. 391). In relation to predatory pricing, depending on the allegation, proof of the possession of market power (e.g., monopolization) or a dangerous probability of attaining it (e.g., attempted monopolization) is required for a firm to be in the position to injure competition through such conduct and, furthermore, to harm consumers through recouping the losses it incurs in doing so. For example, in Liggett Group Inc. v. Brown \& Williamson Tobacco Corp. (1990), to demonstrate predatory pricing, Liggett was required to prove that Brown \& Williamson Tobacco had a sufficient or realistic prospect of market power to lessen competition substantially in the relevant market (see also London, Robinson, and Robinson 1989). Market power can be proved by direct evidence of the actual exercise of control over prices or the actual exclusion of competition, but because such evidence is seldom readily available, courts often consider indirect evidence of market power-most significantly, but not exclusively, an alleged predator's market share of the relevant market and the existence of barriers to entry.

\section{Domain of Power}

Prior investigations of predatory pricing in the airline industry have tended to inquire as to a predator's market power within a market defined as the relevant "city pair" (U.S. Department of Justice v. AMR Corporation 1999). However, some contend that consideration should also be given to power held in the hub market of the dominant airline (see, e.g., Borenstein 1989). According to the DOT (2001), unfair and exclusionary conduct occurs because the national/ network airlines have divided the national market into several regions, with each airline concentrating on certain hub airports. They do not enter into one another's hubs extensively because of fear of price wars or retaliation at their

5Congress has placed a premium on competition in the air transportation industry with the policy goals enumerated in 49 U.S.C. 40101. Thus, the DOT has a mandate to foster and encourage legitimate competition. According to the DOT (2001) report, however, some observed responses from major airlines appear to stray beyond the confines of legitimate competition into the region of unfair competition. 
own hub airports. As the DOT found, a large national airline can obtain various competitive advantages, such as greater name recognition and patronage, as a result of extensive connections from its hubs. Thus, "[t]he ability of airlines to gain and keep market power in hub markets" (p. 5) was an important consideration in the DOT's investigation of complaints of unfair and exclusionary conduct. Consequently, we argue that market power should be more broadly conceived than that which is possessed in a defined city pair to include both the city pair and the relevant hub airport.

\section{Countervailing Power}

Modern scholars in economics and marketing argue that the asymmetry of power between a dominant firm and its competitors should be an important consideration for understanding market power when investigating allegations of predatory pricing (Guiltinan and Gundlach 1996; Kate and Neils 2002). ${ }^{6}$ Kate and Niels (2002, p. 19) point out that though size asymmetries can yield effective facilitating conditions for predatory pricing, "[i]n the post-Chicago models, the issue of relative size is simply not addressed." 7 They note that in the event of a price war against a small (large) competitor with less (more) countervailing power, a dominant firm is more likely to win (lose) because of the asymmetries in information bases and financial resources.

Because a larger firm is likely to be present in multiple markets, the firm may be able to cross-subsidize the losses it incurs in a price war with a small competitor. In addition, customers might have a tendency to switch to the larger firm's brand (see, e.g., the literature on asymmetric switching; Dowling and Uncles 1997). In the airline industry, customers may prefer an airline with better name recognition and more frequent services to a given destination city. Finally, supplies to a smaller rival may be easier to disrupt because its business may be less lucrative for its channel members and trade partners. Thus, aggressive pricing by a larger firm is more likely to result in the quick exit or a significant output reduction by a relatively smaller rival (Guiltinan and Gundlach 1996).

The DOT (2001) asserts that aggressive pricing against a small competitor with less countervailing power can make economic sense if the incumbent firm is able to discipline the competitor or force it to exit the market. Consequently, unreasonably aggressive responses that "[s]eemed designed to keep the new entrant airline from obtaining enough passengers to operate profitably" (p. 7) may warrant further investigation, especially if the competitor is forced from the market. Thus, we contend that the definition of market power may benefit from an elaboration that includes not only the market power of the allegedly predatory firm but

\footnotetext{
${ }^{6}$ Relative power theory argues that the greater the power asymmetry in favor of the attacker, the smaller is the likelihood that the competitor will retaliate (Dekimpe et al. 2001; Molm 1990). Consequently, a dominant firm is not likely to employ aggressive or predatory pricing against a stronger competitor because of fear of retaliation, uncertainty about the outcomes, and the possibility of huge losses that may be difficult to recoup.

${ }^{7}$ Kate and Niels (2002) use the terms "Chicago school" and "postChicago school" to describe the two well-known modern schools of thought in antitrust. These schools have adopted contrasting perspectives, the former against the plausibility of predatory pricing and the latter pointing to the possibility of predatory pricing.
}

also consideration of the countervailing power of the competitor.

\section{Barriers to Entry}

According to the Supreme Court, barriers to entry include either (1) a cost that a firm attempting to enter the defined market would incur that is not borne by an incumbent or (2) any condition that is likely to inhibit other firms from entering the market on a substantial scale (Matsushita Electric Industrial Company v. Zenith Radio Corporation 1986). Barriers to entry that the courts have identified include legal license requirements; control of natural advantages or supplies; and specialized marketing practices, including exclusivity arrangements (see Antitrust Law Developments 2002). In evaluating barriers to entry, courts may consider evidence in relation to the frequency, magnitude, and success of entry. When barriers to entry are found to be significant, courts are more likely to find monopoly power.

With respect to the airline industry, the DOT (2001) recognized that an incumbent can control the marketplace with long-term contracts and relationships with suppliers and distributors, and these conditions may directly or indirectly increase the costs for firms entering that market. Specifically, the DOT contends that in "gate- and slot-controlled" airports, a new entrant may face the entry barrier of needing to pay large fees to the incumbent to sublease gates. In such circumstances, control of these leases can create barriers to entry that enhance the incumbent's market power. Thus, we contend that consideration of these entry barriers is important for fully understanding and assessing market power within the airline industry.

\section{Predatory Conduct}

When an alleged predator is determined to be in possession of monopoly power (or a dangerous probability of achieving it), judicial inquiry turns to its pricing conduct. As we described previously, the Supreme Court has held that below-cost pricing is a necessary element for proving predatory pricing. However, the Court has repeatedly declined to state what precise measure of below-cost pricing is dispositive for this purpose. In the absence of definitive guidance by the Court, considerable attention by scholars has attended to this determination with conflicting opinions and case law present in the courts. Although virtually all modern courts apply a below-cost-based test, differences in opinion continue to exist regarding the use of average variable cost versus average total cost and the nature of inferences and burdens of proof that attend such findings (see American Bar Association 2002).

In academic circles, discourse among scholars has involved consideration of predatory conduct more broadly and has included deliberations about whether above-cost pricing should ever be considered predatory. Some economists argue that predatory pricing can occur at prices that are above cost. For example, Edlin (2002, p. 943) points out that pricing below average variable costs may be a "sufficient but not necessary condition" for predatory pricing, because a dominant firm may be able to exclude more efficient rivals without needing to reduce its prices below the average variable cost. Other economists believe that a dominant firm's charging of prices that are above cost can be 
predatory if the firm dominates the market and that the entry of other firms will be unlikely if the firm can force out a competitor (Ordover and Willig 1981).

Such circumstances may occur when competition in an industry is dependent on scale economies and does not involve pure price competition. For example, when equal or more efficient rivals are relatively small, a dominant firm's scale could exclude them even at prices above its average variable costs. These circumstances are arguably present within the airline industry in which, as the DOT (2001, p. 74) notes, "any relative efficiency of network airlines is the result of larger scale of operations, particularly at their hubs." Similarly, a requirement of pricing below average costs may not be sufficient when customers choose on the basis of attributes other than price, such as when customers are not familiar with competitors' offerings or their decisions are heavily influenced by attributes such as brand equity or previous experience with the dominant brand.

\section{Profit-Maximizing Response Standard}

Considering such factors, the DOT (2001, p. 73) "did not use a cost standard" for its assessment of complaints that allege predatory pricing, finding that "the characteristics of the airline industry may well justify the use of a test for unlawfulness other than a cost standard." Instead, the DOT proposed to examine "pricing and capacity conduct" and "whether the incumbent airline's response to new competition reasonably appeared to be the profit-maximizing response" (p. 73). The DOT concluded that a profitmaximization standard would yield better guidance than a cost standard in determining when a hubbing airline's response to new competition appears to be an unfair method of competition. As the DOT further states (p. 73),

We continue to believe that enforcement action may be appropriate if an incumbent airline cuts its fares and sells many more discount-fare seats in a situation where that response appears to be economically irrational unless the response successfully forces the entrant airline to exit the market.

For applying its profit-maximizing standard, the DOT considers various factors, including whether the response of an incumbent airline to the entry of new competition reasonably appears to be profit maximizing or, alternatively, predatory in nature. Thus, an important consideration involves examination of the way an airline with market power responds through its pricing and capacity decisions to the entry of new competition. As described subsequently, we explore the relationship of market power held by an incumbent airline to both its pricing behavior and its capacity-related decisions. In particular, a contention we examine is whether the extent to which the market power is held by the airline can affect this assessment. For example, consider two firms (airlines), A and B, both with market power in their respective markets. Assume that they serve 100,000 passengers in each market in a given period, their breakeven point is 8000 passengers, and they compete against a single rival. Firm A has a $90 \%$ market share (90,000 passengers; thus, its rival has 10,000 or fewer passengers), and Firm B has a 70\% market share (70,000 passengers; thus, its rival has 30,000 or fewer). All else being equal, is there a difference in the amount that Firms $\mathrm{A}$ and $\mathrm{B}$ need to reduce prices to exclude their respective rivals?
Assuming that passengers for the two firms react similarly to price, Firm A may need a lesser price cut than Firm B to exclude its rival because it would need to attract only 2000 passengers from its rival, whereas Firm B would need to attract 22,000, or 11 times more, passengers to make its respective rivals' operations unprofitable. Thus, the determination of whether a price response (e.g., cut) is profit maximizing (or, alternatively, potentially predatory) may benefit from consideration of the airline's market power, together with other factors.

\section{Volume (Capacity) Expansion}

Although not considered to be an element of inquiry by the Supreme Court, as we noted previously, the DOT (2001, p. 68 ) and others propose that in addition to price, the capacity conduct of an alleged predator to infer competitive injury should be considered. Areeda and Hovenkamp (2000) stress the notion that injury to competition is sourced in that which a predator causes to a competitor by taking away its sales through deep price cuts. According to Areeda and Hovenkamp, an expansion into the dominant firm's sales volume, which indicates the impact of its price cutting, is required, along with a deep price cut, to infer predatory pricing. Similarly, the DOT (2001, p. 73, emphasis added) notes that "[e]conomists have recognized that consumers are harmed if a dominant firm eliminates competition from firms of equal or greater efficiency, by cutting its prices and increasing its capacity, even if its prices are not below costs." On the basis of such considerations, the DOT (2001, p. 68) report contends that " $[\mathrm{t}]$ he Department should not consider investigating the incumbent airline's matching of an entrant's fares unless the incumbent airline greatly increases the availability of low-fare seats or adds capacity." Thus, the DOT identifies as objectionable conduct a combination of price cuts and capacity additions by incumbent airlines that have the result of producing lower local revenue than would a reasonable alternative response (Kahn 2000).

Similarly, echoing the words of Ordover and Willig (1981, p. 8), we argue that "the existence of profit sacrifice is not itself sufficient for a finding of predation," and the actual impact of price cuts must be considered. Namely, does the price cut also exclude the targeted competitor through a predatory attack on its volume? As such, we contend that predatory conduct should be assessed broadly and, with regard to the predatory firm, should include an examination of both price cuts and any related volume expansion. If a dominant firm with high market power accompanies deep price cuts with large volume expansions, its conduct may be termed aggressive (and potentially predatory if certain other conditions, such as injury to competition and recoupment, are met). 8 Thus, both price cutting and volume expansion are important considerations and should be examined simultaneously to understand predatory conduct fully in the airline industry.

\footnotetext{
${ }^{8}$ It may be argued that volume expansion is a natural response to price reductions in that a reduction in prices automatically results in volume expansion, and similarly, a volume expansion automatically depresses prices in a market. We account for these effects in the first portion of our simultaneous equation model.
} 


\section{Recoupment}

According to the Supreme Court, "[r]ecoupment is the ultimate object of an unlawful predatory pricing scheme; it is the means by which a predator profits from predation" (Brooke Group Ltd. v. Brown Williamson Tobacco Corp. 1993, pp. 224-25). To determine whether the prospect of recoupment exists, according to the Court, there must be the likelihood that the alleged predator's pricing will drive the intended target from the market and that, given relevant considerations (i.e., market shares, ease of entry, excess capacity, and all other pertinent factors), following the victim's exit, the market is susceptible to monopoly pricing. Actual recoupment involves a predator, having caused the exit of targeted rivals through its pricing conduct, increasing its prices to monopoly levels to recover any losses it incurred and to exploit its monopoly power. Recoupment results in higher prices not because of better products or increasing demand but because of reduced competition in the marketplace.

The DOT (2001) report cites several cases in which a dominant incumbent airline cut its fare in half on the entry of a discount airline and then increased the fares beyond the previous level (almost doubled) after the discount airline exited the market. However, proving recoupment may be difficult. Hemphill (2001) indicates that a deeper price cut requires higher price increases to recover the losses incurred than does a lower price cut. Consequently, recoupment may be easier in the case of lower price cuts. Hemphill asserts ( $\mathrm{p}$. 1597) that "simply adding predation losses and postpredation gains compared to a zero-profits baseline, gives an incorrect result. Where the alternative to predation is substantial losses, the true recoupment point is lower than the zero-profit point, and recoupment is easier to satisfy than the zero-profit baseline assumes."

In addition, Guiltinan and Gundlach (1996) note that managers of firms that are intent on predation may calculate higher probabilities of recoupment erroneously because they may not be able to account for all market and economic conditions at the time of their strategy formulation. Thus, predatory conduct (e.g., price cutting) could occur even without an actual dangerous probability of recoupment. Given this potential, we advocate differentiation between managers' views, at the time of strategy formation, about whether they can recoup and a court's assessment of whether recoupment is likely. Although the former is informative to the question of whether a dangerous probability of recoupment exists, we suggest that the latter should be considered controlling to the extent that it focuses on the likely real effects of higher prices in the marketplace.

\section{An Empirical Examination of the Airline Industry}

To investigate aspects of our previously developed insights, we conducted empirical research within the airline industry. Our research involved an exploratory survey that provided insights into the importance and perceptions of predatory pricing on the part of airline executives and empirical analyses that examined the Supreme Court's elements for proving allegations of predatory conduct in the airline industry, as informed by aspects of the "newer" thinking and considerations that are important to the DOT's investigation. Our empirical analysis investigated patterns of increasing concentration on the part of major airlines in hub airports and a major airline's price-cutting response to the entry of discount airlines over time. We also examined the relationship between market power and pricing-related conduct through a simultaneous equation model to gain further insights.

\section{Exploratory Survey}

As an initial effort to establish the importance of predatory pricing as a business issue and a concern within the airline industry, we conducted an exploratory survey of discount airline executives by contacting vice presidents and other high-ranking officials in the industry; we received responses from five of the ten respondents. Using a ten-point scale $(1=$ "not significant," and 10 = "very significant"), we asked respondents: "How important is predatory pricing as a business issue or concern?" The average response was 9 . We also asked respondents, "Have you exited a city-pair market due to predatory pricing?" All respondents answered yes, and the number of routes exited ranged from 1 to 18 . The survey further indicated that the discount airlines executives believed that major airlines used predatory pricing mainly against small discount airlines, and the discounters claimed that they were often forced from markets or to reduce their capacity as a result of such conduct.

\section{Empirical Analysis}

Findings from the exploratory survey supported our subsequent empirical analysis, which examined pricing-related conduct in the airline industry. We carried out three analyses. First, we examined market power through consideration of concentration and yields over time in the 50 largest domestic airports, including the 17 hub airports of major national airlines. Second, we focused on a specific major airline to examine patterns of its price cutting in response to the entry of a new discount airline in its markets. Third, we developed and estimated a simultaneous equation model that examined the association of pricing-related conduct on the part of the major airlines and their market power.

We obtained the data used for our empirical analyses from an Airline Origin and Destinations Survey (DB1B; see http://www.transtats.bts.gov) of air passenger traffic. The data set contains fares and passenger information for a sample of $10 \%$ of all passengers on all domestic flights in the United States on a quarterly basis during 1991-1999. The data also provide information about flights from a base airport to a destination airport (or a city-pair market). This information includes passenger volume for a given airline (i.e., the number of passengers flying a given airline between two airports in a given quarter), entry and exit of an airline, and the average fare between two airports for a given airline in a market in a quarter. Using this information, we derived the variables of interest included in the three empirical studies.

\section{Market Power of the Major Airlines}

\section{Airport Concentration}

As a basis for examining the presence and pattern of market power among the major airlines, applying insights into the domain of power, we studied the airport concentration in the 
top 50 U.S. airports, comparing 17 hub airports with 33 nonhub airports from 1984 to 1999 (see Figure 1). We identified hub airports through consultation of General Accounting Office reports and DOT reports. We measured concentration in these airports with the Herfindahl-Hirschman Index (HHI). We calculated the HHI by summing the squares of the percentage market shares held by the respective firms; higher HHIs reflected higher concentration. As we show in Figure 1, HHIs for the 17 hub airports studied were higher in magnitude and increased over time from 1984 to 1999 than the HHIs for the 33 nonhub airports, which were lower in magnitude and had little increase over time. Together, these data provide evidence of increasing concentration in these 17 airports compared with 33 nonhub airports.

\section{Yield Premium}

As a basis for further examining the presence and pattern of market power among the major airlines, we studied the yield premiums for 17 hub airports (together with 2 slotcontrolled airports) from 1990 to 1999 (see Figure 2)..$^{9}$ In addition to market share, evidence of market power may be captured through consideration of pricing trends and, in

${ }^{9}$ The 2 slot-controlled airports behaved differently from the 31 nonhub airports in terms of yield. Therefore, we computed the yield premiums in these airports separately. Adding the yield premium of these 2 slotcontrolled airports to the yield premium at the 17 hub airports further increased the average yield premium. some cases, evidence of high prices. We defined "yield" as the revenue per passenger mile or fare per passenger mile. We used this standardization for comparability of fares across city pairs of different distances. We computed yield premiums by taking the ratio of the average yields in the 17 hub (plus 2 slot-controlled airports) airports to the average yields in 31 nonhub airports (33 less the 2 slot-controlled airports) and converted the resultant ratios into a percentage (e.g., the ratio less 1 times 100). We then fitted a line (1) to the data for the 17 hub airports and (2) for the 17 hub airports plus the 2 slot-controlled airports. The results indicate that the yield premiums in the hub airports and the hub plus slot-controlled airports have increased over time (see Figure 2).

\section{Price Response by a Major Airline to the Entry and Exit of Discount Airlines}

To examine the pattern of conduct (e.g., price cut, recoupment) specified by the Supreme Court for proving allegations of predatory pricing, we investigated the price response of a major airline, whose name is withheld for confidentiality reasons, to the entry and exit of discount airlines for several routes (e.g., city pairs) it serves and, in addition, its pricing behavior in markets into which no discount airline entered. At random, we chose 15 routes of a major airline for which there were no low-fare (discount) competitors and 15 routes for which discount airlines entered the major airline's market and were met by a price response. For the chosen markets, we examined the major airline's price

Figure 1. Increasing Market Power of Major Airlines in Hub Airports

Increasing Concentration in 17 Hub Airports as Compared with 33 Nonhub Airports from 1984 to 1999

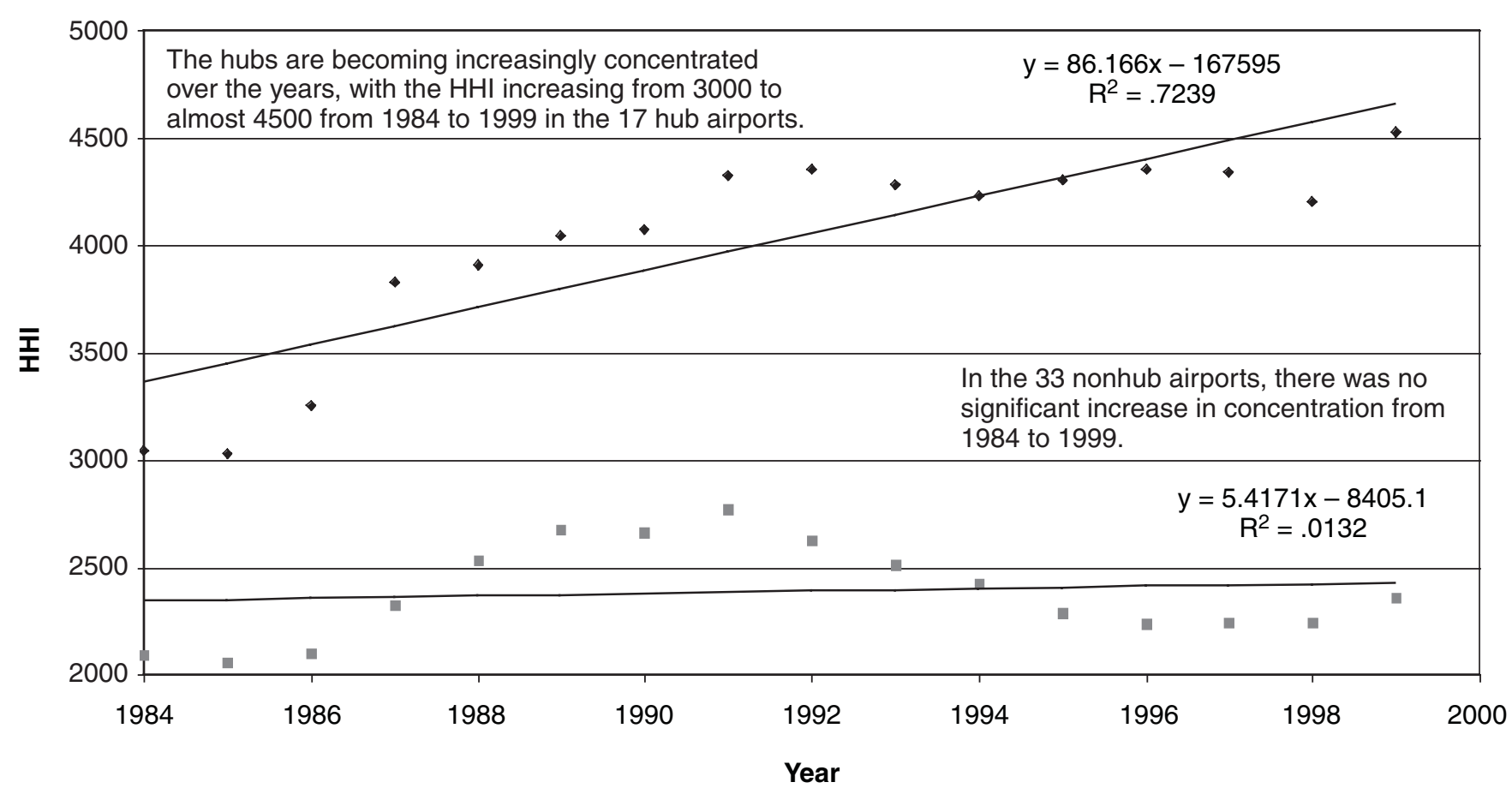


Figure 2. Increasing Yield Premium of Major Airlines in Hub Airports

Yield Premium for 19 Airports (17 Hub and 2 Slot-Controlled Airports) and for 17 Hub Airports of Major Airlines

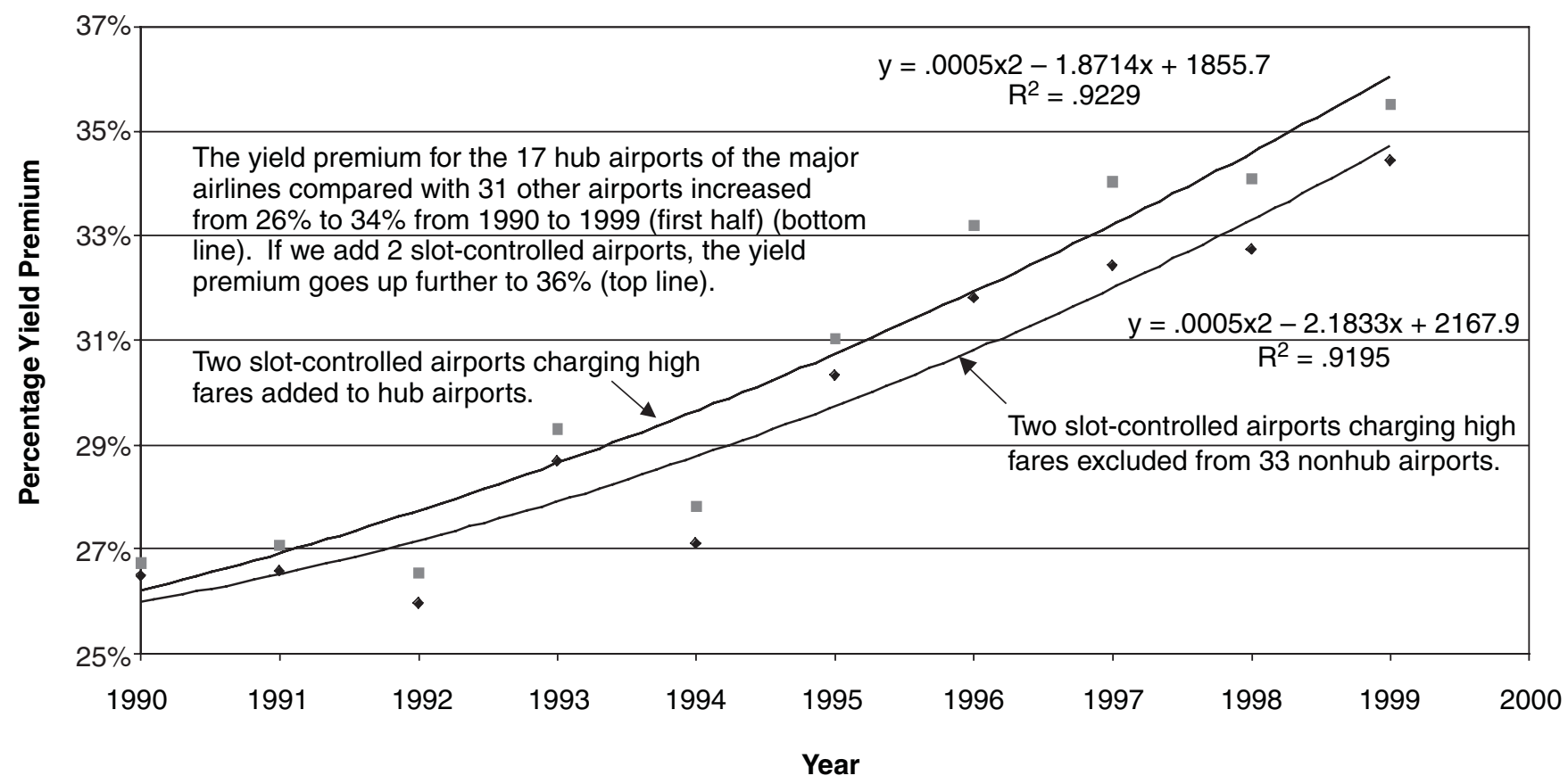

responses to the entry of the discount airlines and compared them with the pricing behavior of the major airline when there was no entry by discount airlines.

For the 15 routes for which there was no entry of a discount airline, our findings reveal that the major airline increased its average price during the 1994-1999 period by $15 \%$ (see Figure 3 ). However, for the 15 routes for which a

\section{Figure 3. Major Airline Increased Its Fares in 15 City-Pair Markets Without a Discount Airline an Average of $15 \%$ from 1994 to 1999}

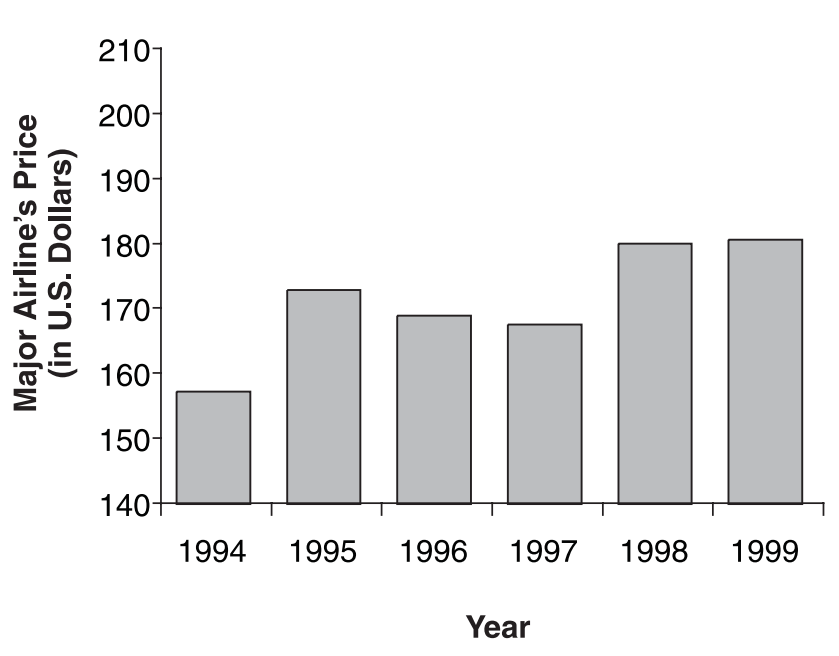

discount airline entered (10 routes in 1993 and 5 routes in 1997-1998), the major airline decreased its average price considerably thereafter (see Figures 4 and 5).

As we show in Figure 6, in the seven markets in which a discount airline entered and then subsequently exited, the dominant airline cut its prices and then increased its prices over time to the same or higher levels than those before the entry of the discounter. However, because the entry and exit periods occurred at different times, we show one representative pattern (see Figure 6).

In a few cases, we were able to examine further the major airline's pricing when a discount airline, after entering and then exiting, reentered (see Figure 7, Location A) and reexited (see Figure 7, Location B) the market again. We find similar pricing responses on the part of the major airline. Although information about costs on the part of the major airline was not observed and its market power in the routes selected is not indicated, these results show a pattern of price cuts in response to the entry (and, in some cases, reentry) of discount airlines that is consistent with the evidence that the Supreme Court requires to determine predatory pricing practices.

\section{Relationship Between Market Power and Pricing-Related Conduct in the Airline Industry}

As a basis for informing considerations of predatory pricing underlying the newer thinking and, in particular, those attendant to the DOT's profit-maximizing response standard, our simultaneous equation model examined the association of the incumbent airline's market power with both its pricing 
Figure 4. Major Airline Cut Its Prices in Ten Early Markets That Discount Airline Entered

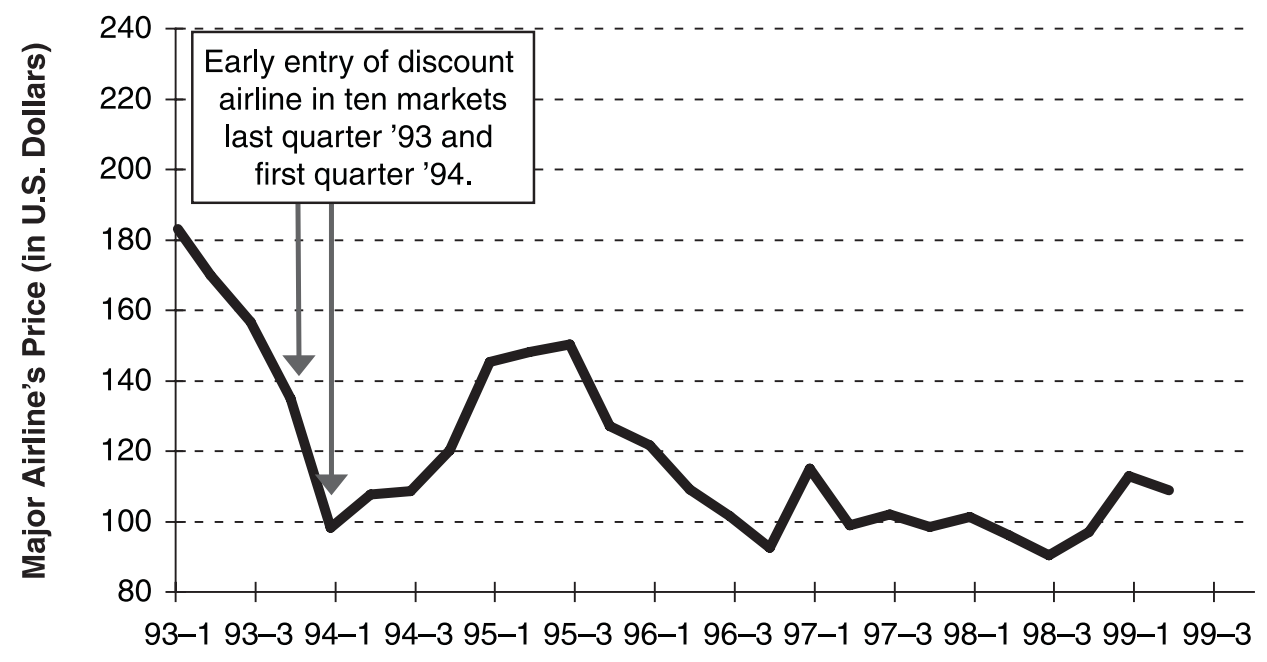

Year-Quarter

Figure 5. Major Airline Cut Its Prices When Discount Airline Entered in Five Markets in 1998

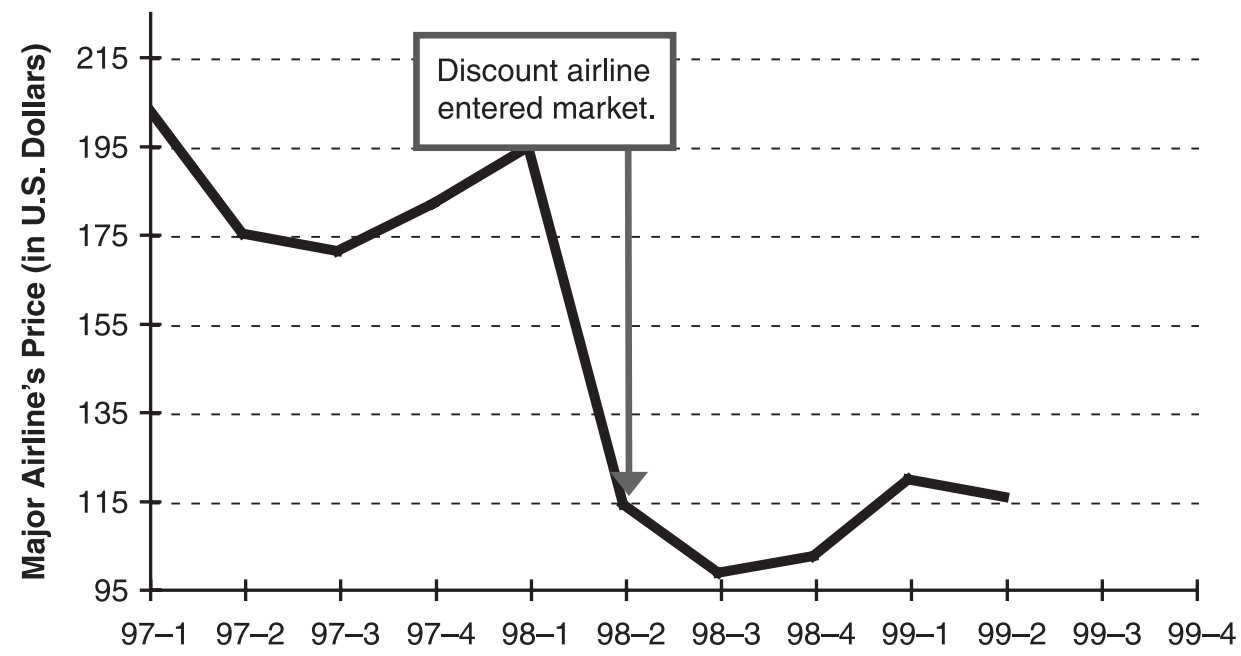

Year-Quarter

behavior and its capacity-related decisions. Recall that for assessing allegations of predatory conduct, the DOT's standard considers whether the response of an incumbent airline to the entry of new competition reasonably appears to be profit maximizing. A particular contention we examine is whether the extent to which the market power held by the airline can affect this assessment. Thus, we examined the relationship between an incumbent airline's market power and pricing-related conduct (e.g., price cutting, volume expansion) by incorporating aspects of the insights we developed previously.
We estimated a simultaneous equation model that associated pricing-related conduct in the form of fare cuts and volume expansion by major airlines with market power as measured through consideration of the major airlines' domain of power, discount airlines' countervailing power, and the presence of barriers to entry in the relevant market. We employed a stratified random sample of 38 markets served by the major airlines that discounters entered during 19911999 and in which they experienced price cuts by the incumbent major airlines, including 9 markets in which the DOT suspected predatory pricing. 
Figure 6. Typical Pattern of Pricing by Major Airlines in Response to Discount Airlines in Several Cities (Described as Before, During, and After Discount Airline Exits)

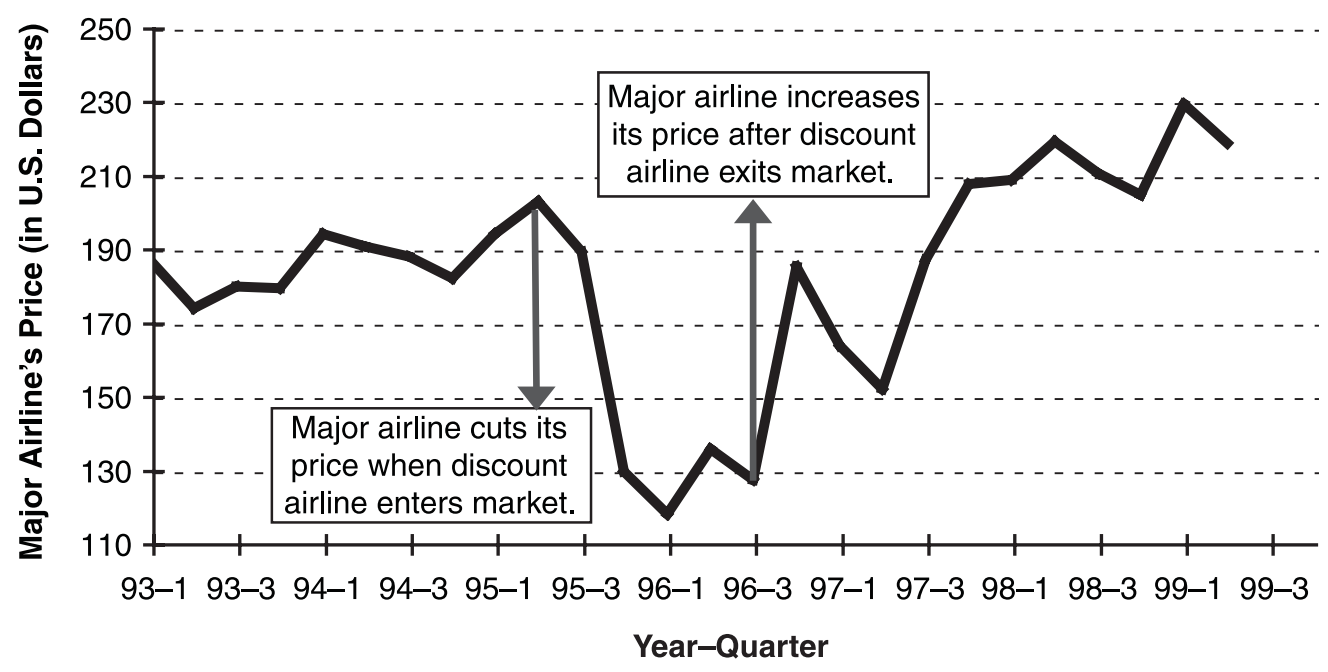

\section{Market Power}

Market power is defined as the power to control market prices or exclude competition. It is measured through consideration of the domain of market power held by the major airlines, the countervailing power held by competing airlines, and barriers to entry present in the markets examined.

Domain of power. In line with the work of Borenstein (1989) and factors that the DOT (2001) identified as important, we considered the major airline's domain of market power, measuring it not only in the relevant city-pair market but in the originating hub airport as well. To operationalize market power across these domains, we computed the market share of the major airline in an individual city-pair market $\left(\mathrm{MKTDOMMS}_{\mathrm{ijt}}\right)$ as the percentage of passengers it flies in that city-pair market (route) in a given quarter. In addition, we computed the market share of a major airline within its hub market $\left(\mathrm{BASEDOMMS}_{\mathrm{it}}\right.$ ) as the percentage of passengers it flies to all cities from that hub in a given quarter. We also calculated the square of the major airline market share in a market (MKTDOMMSSQ) so that its use in the model would allow for the identification of nonlinear relationships with other variables.

Countervailing power. Scholars in both economics and marketing contend that the asymmetry of power between a dominant firm and its competitors should be considered in the assessment of market power when investigating allegations of predatory pricing (Guiltinan and Gundlach 1996; Kate and Neils 2002). On the basis of these contentions, we examined the countervailing power held by competing discount airlines. Extending insights derived from our foregoing consideration of market power domain, we computed two measures of the discount airlines' countervailing power. We measured the discount airlines' countervailing power on the basis of its market share in the relevant city-pair market, calculated by the percentage of passengers flown by the relevant discount carrier in a city-pair market ij in quarter $t$ (DISCOUNTMS $\mathrm{ijt}_{\mathrm{it}}$ ), and the discount airlines' overall size, calculated by the number of domestic passengers carried in all markets (DISCOUNTSIZE). We also calculated the square of the discount airline market share in the city-pair market (DISCOUNTMSSQ) so that its use in the model would allow for the identification of nonlinear relationships with other variables.

Barriers to entry. Entry barriers included either a cost that a firm attempting to enter a defined market would incur that is not borne by an incumbent or any condition that is likely to inhibit other firms on a substantial scale from entering the market. The DOT (2001) recognizes several barriers to entry in the airline industry, including gate controls and slot controls. Gate-controlled airports are those in which the gates and aircraft parking positions are controlled by long-term leases with incumbent airlines. Slot controls refer to federal rules that set hourly quotas for takeoffs and landings at the busiest airports. Barriers to entry are created when incumbents in such airports have long-term leases for the airports' slots. A new entrant may be able to lease slots on a shortterm basis from a major carrier, but the cost of the slots and the short-term agreements deter new entrants. A U.S. General Accounting Office (1996) report shows that during the relevant period, the major airlines and their feeder carriers leased $96 \%$ of the domestic slots in four slot-controlled airports. Therefore, we operationalized barriers to entry (BARRIER) by employing a dummy variable that takes the value of 1 if there is gate control or slot control at either of the two cities of a city-pair market and 0 if otherwise.

\section{Pricing-Related Conduct}

Although the Supreme Court has held that below-cost pricing is a necessary element for proving predatory pricing, academic discourse among scholars has involved consideration of predatory conduct more broadly and has included deliberations as to whether above-cost pricing should ever be considered predatory. In the DOT's (2001, p. 73) investigation of the airline industry, it "did not use a cost standard," finding that "the characteristics of the airline industry 
Figure 7. Major Airline's Response to Discount Airlines' Reentry

Location A: Major Airline Cut Its Price, Raised Its Price, and Cut Its Price Again as Discount Airlines Entered, Exited, and Reentered the Market

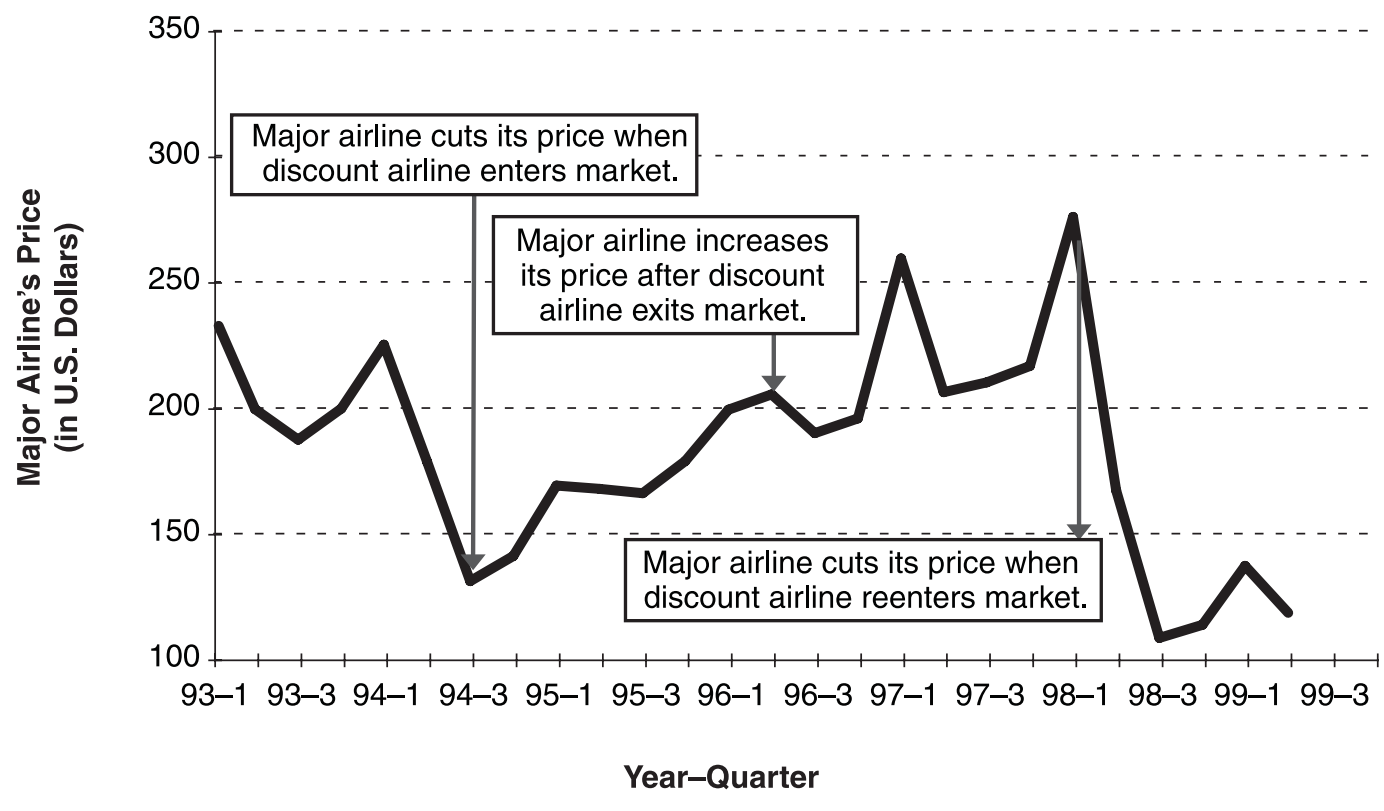

Location B: Major Airline Cut Its Price, Raised Its Price, Cut Its Price, and Raised Its Price Again as Discount Airline Entered and Reentered the Market

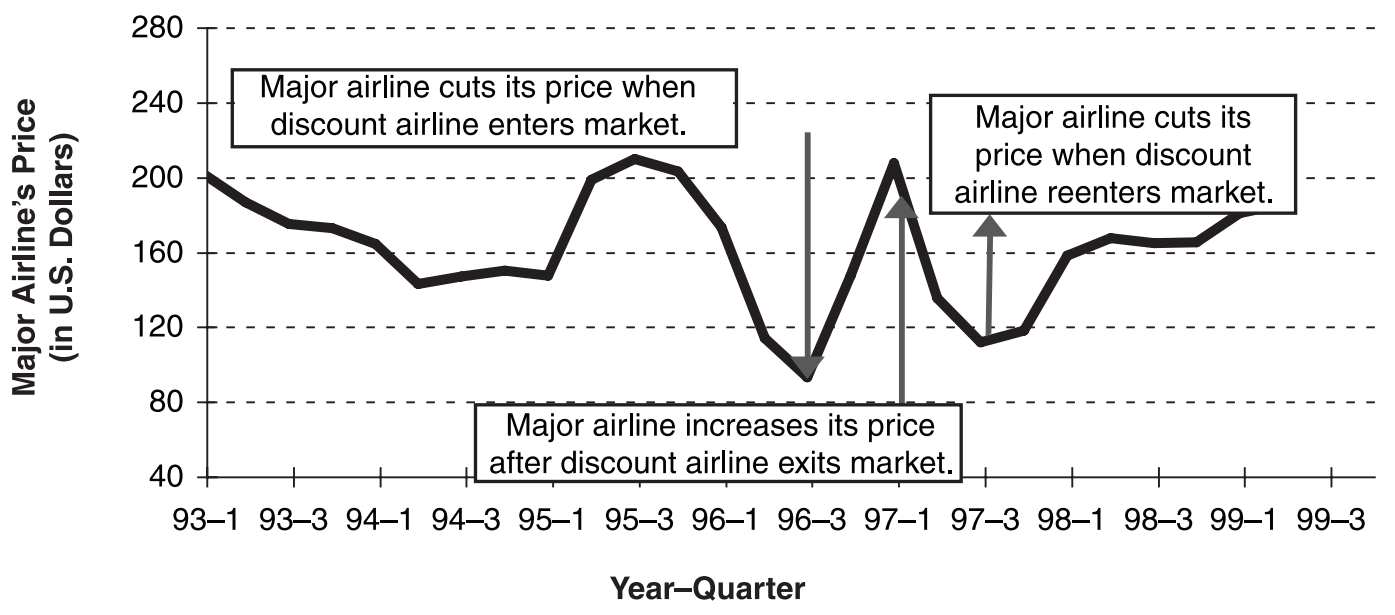

may well justify the use of a test for unlawfulness other than a cost standard." Instead, viewing predatory conduct broadly, the DOT examined "pricing and capacity conduct," inquiring "whether the incumbent airline's response to new competition reasonably appeared to be the profitmaximizing response" (p. 73, emphasis added). In line with this broadened perspective, to measure pricing-related conduct, we examined the major airline's changes to its fares (e.g., price response) and volume (e.g., volume expansion) at the time of the discount airlines' entry.
Price response. To compute fare changes (PRICECUT), we used the percentage change between the average fare of the major airline in a city-pair market ij for the four quarters before time $t$ and the average fare one quarter after time $t$. We used the four-quarter difference to control for seasonal variations.

Volume expansion. We computed volume expansion-the increase in sales of the major airline in market ij during the quarter $\mathrm{t}$ in which the discount airline entered-as the per- 
centage change between the average number of passengers of the major airline in the four quarters before time $t$ and the average number one quarter after time $t$.

\section{Simultaneous Equation Model}

We estimated a model in which the price cut (PRICECUT) and volume expansion (VOLUMEXP) variables measuring pricing-related conduct are endogenous. Because they are endogenous, we employed a simultaneous equation model that captures the effects of PRICECUT on VOLUMEXP, and vice versa (see Dresner and Tretheway 1992). Each captures the effects of the various exogenous variables.

A model is considered identified if it fulfills rank-andorder conditions (Wooldridge 2002). Because PRICECUT is dependant on VOLUMEXP, and vice versa, we attempted to find a variable that does not affect the PRICECUT but affects the VOLUMEXP, and vice versa. We assumed that the major airline would match the prices of the discounter. As a result, we did not employ discounter market share (DISCOUNTMS) as an exogenous variable in the PRICECUT equation. Furthermore, we assumed that volume expansion (VOLUMEXP) was not likely to depend on a major airline's market share, and therefore we did not employ the major airline's market share (MKTDOMMS) in the volume expansion (VOLUMEXP) equation. This is sufficient for identification because the rank-and-order conditions are met (Wooldridge 2002). The following equation represents the model we estimated:

(1) $\left[\begin{array}{c}\operatorname{PRICECUT}_{\mathrm{ijt}} \\ \operatorname{VOLUMEXP}_{\mathrm{ijt}}\end{array}\right]=\left[\begin{array}{cc}0 & \beta_{2} \\ \beta_{1} & 0\end{array}\right]\left[\begin{array}{c}\operatorname{PRICECUT}_{\mathrm{ijt}} \\ \operatorname{VOLUMEXP}_{\mathrm{ijt}}\end{array}\right]$

$$
+\left[\begin{array}{ccccccc}
\gamma_{1} & \gamma_{2} & \gamma_{3} & \gamma_{4} & 0 & 0 & \gamma_{5} \\
\gamma_{6} & 0 & 0 & \gamma_{7} & \gamma_{8} & \gamma_{9} & \gamma_{10}
\end{array}\right]
$$

$\left[\begin{array}{l}\text { BASEDOMMS }_{\mathrm{it}} \\ \text { MKTDOMMS }_{\mathrm{ijt}} \\ \text { MKTDOMMSSQ }_{\mathrm{ijt}} \\ \text { BARRIER }_{\mathrm{ij}} \\ \text { DISCOUNTMS }_{\mathrm{ijt}} \\ \text { DISCOUNTMSSQ }_{\mathrm{ijt}} \\ \text { DISCOUNTSIZE }_{\mathrm{t}}\end{array}\right]+\left[\begin{array}{l}\varepsilon_{1} \\ \varepsilon_{2}\end{array}\right]$,

where

$$
\begin{aligned}
\text { PRICECUT }_{\mathrm{ijt}}= & \text { the major airline's fare reduction in a } \\
& \text { given quarter } \mathrm{t} \text { from its average fare one } \\
& \text { year before the entry of the discount } \\
& \text { airline in a given city-pair market } \mathrm{ij} ; \\
\text { VOLUMEXP }_{\mathrm{ijt}}= & \text { the increase in passengers in a given } \\
& \text { quarter } \mathrm{t} \text { from the average passengers } \\
& \text { per quarter of the major airline one year } \\
& \text { before the entry of the discount airline } \\
& \text { in a given city-pair market ij; } \\
\text { BASEDOMMS }_{\mathrm{it}}= & \text { the market share of the major airline for } \\
& \text { all flights to all cities from a base city } \mathrm{i} \\
& \text { in a given quarter } \mathrm{t}, \text { a dummy variable }
\end{aligned}
$$

that takes a value of 1 if the market share of the major airline in the base airport is $60 \%$ or more and 0 if otherwise;

MKTDOMMS $_{\mathrm{ijt}}=$ the market share of the major airline in a city-pair market ij for a given quarter $\mathrm{t}$;

MKTDOMMSSQ $_{i j t}=$ the square of market share of the major airline in a city-pair market ij for a given quarter $\mathrm{t}$;

BARRIER $_{\mathrm{ij}}=$ a dummy variable that takes the value of 1 if there is gate control or slot control at either of the two cities of a citypair market ij and 0 if otherwise;

DISCOUNTMS $_{\mathrm{ijt}}=$ the market share of the discount airline in a city-pair market $\mathrm{ij}$ for a given quarter $\mathrm{t}$;

DISCOUNTMSSQ $_{i j t}=$ the square of the market share of the discount airline in a city-pair market ij for a given quarter $\mathrm{t}$; and

DISCOUNTSIZE $=$ the size of the competitor in terms of the total number of passengers carried in all markets since its inception.

\section{Model Estimation and Results}

The estimated simultaneous equation model provides insights into the relationship between pricing-related conduct and market power. Table 1 presents the descriptive statistics for the included variables.

Domain of power and pricing-related conduct. The results of the simultaneous equation model indicate that the market share of the major airline in the hub airport (BASEDOMMS) and in the city-pair markets (MKTDOMMS) is positively and significantly related to price cuts (PRICECUT) $(\alpha<.01)$; however, the coefficient of the square term (MKTDOMMSSQ) is negative, indicating a nonlinear relationship. Furthermore, the results indicate that the market share of the major airline in the hub airport (BASEDOMMS) is negatively and significantly related to volume expansion (VOLUMEXP). The results related to price cuts indicate that the price-cutting responses of the major airline to the entry of discounters tended to increase at a decreasing rate as the market power of the major airline increased in its relevant city-pair markets but then decreased after a certain level of market power (approximately 60\%-70\%). The results related to volume expansion indicate that the volume expansion responses of the major airline to the entry of discount airlines tended to decrease as the major airline's market share in the hub increased. Together, these results indicate that it may be important to consider market power and, in particular, the domain of market power when making assessments of whether a response on the part of an incumbent airline to the entry of new competition reasonably appears to be profit maximizing.

Countervailing power and pricing-related conduct. The volume expansion (VOLUMEXP) behavior of the major airlines is significantly $(\alpha<.01)$ and positively related to the market share of the discount airlines (DISCOUNTMS), and the coefficient of the square term (DISCOUNTMSSQ) is 


\begin{tabular}{|c|c|c|}
\hline \multirow{2}{*}{$\begin{array}{l}\text { Table } 1 . \\
\text { Variable }\end{array}$} & \multicolumn{2}{|c|}{$\begin{array}{l}\text { Simultaneous Equation Model of Price Cut and } \\
\text { Volume Expansion Reactions }\end{array}$} \\
\hline & & M (SD) \\
\hline \multicolumn{3}{|c|}{ Endogenous } \\
\hline $\begin{array}{l}\text { Reduct } \\
\text { give } \\
\text { the } n \\
\text { entry } \\
\text { city- }\end{array}$ & $\begin{array}{l}n \text { in fare of the major airline in a } \\
\text { quarter } t \text { from the average fare of } \\
\text { jor airline, one year before the } \\
\text { f the discount airline in a given } \\
\text { ir market ij (PRICECUT } \text { PRt }^{\text {PR }}\end{array}$ & $\begin{array}{l}.1516 \\
(.3063)\end{array}$ \\
\hline $\begin{array}{l}\text { Increas } \\
\text { from } \\
\text { of th } \\
\text { entry } \\
\text { city- }\end{array}$ & $\begin{array}{l}\text { in passengers in a given quarter } t \\
\text { he average passengers per quarter } \\
\text { major airline, one year before the } \\
\text { f the discount airline in a given } \\
\text { ir market ij (VOLUMEXP }{ }_{\mathrm{ijt}} \text { ) }\end{array}$ & $\begin{array}{l}.2755 \\
(.3482)\end{array}$ \\
\hline \multicolumn{3}{|c|}{ Exogenous } \\
\hline $\begin{array}{l}\text { Market } \\
\text { on a } \\
i \text { in }\end{array}$ & $\begin{array}{l}\text { hare (dummy) of the major airline } \\
\text { flights to all cities from a base city } \\
\text { siven quarter (BASEDOMMS } \\
\text { it })\end{array}$ & $\begin{array}{l}.4376 \\
(.4965)\end{array}$ \\
\hline $\begin{array}{l}\text { Market } \\
\text { pair } \\
\text { (MK }\end{array}$ & $\begin{array}{l}\text { hare of the major airline in a city- } \\
\text { arket ij for a given quarter } t \\
\text { DOMMS }_{\mathrm{ijt}} \text { ) }\end{array}$ & $\begin{array}{c}65.9227 \\
(14.7989)\end{array}$ \\
\hline $\begin{array}{l}\text { A dum } \\
\text { gate } \\
\text { the } t \\
0 \text { if }\end{array}$ & $\begin{array}{l}\text { y variable captured by } 1 \text { if there is } \\
\text { ontrol or slot control at either of } \\
\text { o cities of a city-pair market ij and }^{\text {herwise } \text { (BARRIER }_{\mathrm{ij}} \text { ) }}\end{array}$ & $\begin{array}{l}.0369 \\
(.1887)\end{array}$ \\
\hline $\begin{array}{l}\text { Market } \\
\text { city- } \\
\text { (DIS }\end{array}$ & $\begin{array}{l}\text { hare of the discount airline in a } \\
\text { air market ij for a given quarter } \mathrm{t} \\
\text { OUNTMS }_{\mathrm{ijt}} \text { ) }\end{array}$ & $\begin{array}{c}21.7347 \\
(14.4925)\end{array}$ \\
\hline $\begin{array}{l}\text { The siz } \\
\text { num } \\
\text { mark }\end{array}$ & $\begin{array}{l}\text { of the discounter in terms of total } \\
\text { ar of passengers carried in all } \\
\text { ts (DISCOUNTSIZE } \text { t }_{t}\end{array}$ & $\begin{array}{c}10,495.52 \\
(19,431.72)\end{array}$ \\
\hline
\end{tabular}

negative, in support of a nonlinear relationship (Table 2). Similarly, the major airline's volume expansion reactions (VOLUMEXP) are significantly and negatively related to the overall size of the discounter (DISCOUNTSIZE). These results indicate that the volume expansion by the major airline increases at a decreasing rate and then decreases after a certain level of market share on the part of the discount airline and that this volume expansion is inversely related to the overall size of the discount airline. Again, taken together, these results indicate that it may be important to consider market power and, in particular, countervailing power of a rival airline when assessing whether an incumbent airline has responded to the entry of new competition in ways that reasonably appear to be profit maximizing.

Barriers to entry and pricing-related conduct. We did not find a significant relationship between the presence of barriers to entry (BARRIER) and conduct (PRICECUT and VOLUMEXP), the interaction effects of the major airline city-pair market share and barriers to entry, or discount airline market share in that city-pair market share and barriers to entry (MKTDOMMS $\times$ BARRIER and DISCOUNTMS $\times$ BARRIER; see Table 2). A potential explanation for these findings may be related to the focus of the measure employed for barriers to entry only in terms of gate and slot control at an airport.

\section{Discussion and Implications}

Our study makes two major contributions. First, through consideration of the newer thinking and the DOT's (2001) investigation of the airline industry, we add to the overall understanding of the three elements that underlie the Supreme Court's requirements for proving predatory pricing. We integrate insights from this new thinking and those obtained through the DOT investigation together with the Supreme Court's required elements and discuss their application within the airline industry. Second, our study is one of a few empirical efforts in this area and within the airline industry in particular. Our descriptive studies show increasing concentration and yield premiums within the major airline hubs. Furthermore, although we do not investigate the costs on the part of a major airline, we show a pattern of price conduct by the major airline in response to the entry (and, in some cases, later exit and reentry) of discount airlines that is consistent with the Supreme Court's requirements. In addition, prompted by the DOT's profitmaximizing response standard for assessing predatory conduct and to address the question of whether the extent to which the market power held by the airline can affect this assessment, we estimated a simultaneous equation model that examined the association of market power held by incumbent major airlines with both their pricing-related behavior and volume capacity decisions. Our findings provide insights into the complex relationship between market power and pricing-related conduct in the airline industry.

\section{Limitations}

Although our study provides insights into the phenomenon of predatory pricing, we note some limitations. The methods and models we apply to study predatory pricing are indicative in nature, and the measures may be limited because of our data restrictions. Furthermore, we recognize that nonpredatory behavior may be influential in cases of predatory pricing and should be taken into account. Finally, although our study of a single industry provides greater understanding of and insights into the phenomenon of predation, other industries should also be investigated.

\section{Public Policy}

Because price is the mechanism through which a firm often stimulates competition, courts, including the Supreme Court, have been circumspect in their assessments of predatory pricing allegations. To avoid mistaken inferences and to protect competition, the Court has mandated stringent elements in law for proving claims of predation. Within the context of the airline industry, our research elaborates on these elements by applying insights from newer thinking in economics and marketing and insights developed through the DOT's (2001) investigation. As such, we further inform extant considerations for assessing allegations of predatory pricing.

With regard to the airline industry, the insights we developed and the findings from our empirical analyses inform and provide further guidance to considerations that the DOT 
Table 2. Simultaneous Equation Model of Price Cut and Volume Expansion: Major Airline's Reactions to Competitor Discount Airline

\begin{tabular}{|c|c|c|}
\hline Variable & $\begin{array}{l}\text { Price Cut } \\
\left(\text { PRICECUT }_{\mathrm{ijt}}\right)\end{array}$ & $\begin{array}{l}\text { Volume Expansion } \\
\left(\text { VOLUMEXP }_{\mathrm{ijt}}\right)\end{array}$ \\
\hline \multicolumn{3}{|l|}{ Endogenous } \\
\hline $\begin{array}{l}\text { Reduction in fare of the major airline in a given quarter } \mathrm{t} \text { from the average fare of } \\
\text { the major airline, one year before the entry of the discount airline in a given } \\
\text { city-pair market ij (PRICECUT }{ }_{\mathrm{ijt}} \text { ) }\end{array}$ & - & $\begin{array}{l}1.2812 * \\
(.1442)\end{array}$ \\
\hline $\begin{array}{l}\text { Increase in passengers in a given quarter t from the average passengers per quarter } \\
\text { of the major airline, one year before the entry of the discount airline in a given } \\
\text { city-pair market ij }\left(V_{\text {VOLUMEXP }} \text { ) }\right.\end{array}$ & $\begin{array}{l}.2861 * \\
(.0993)\end{array}$ & - \\
\hline \multicolumn{3}{|l|}{ Exogenous } \\
\hline $\begin{array}{l}\text { Market share (dummy) of the major airline on all flights to all cities from a base } \\
\text { city i in a given quarter (BASEDOMMS }{ }_{\text {it }} \text { ) }\end{array}$ & $\begin{array}{l}.2817 * \\
(.0438)\end{array}$ & $\begin{array}{c}-.1559 * \\
(.0629)\end{array}$ \\
\hline $\begin{array}{l}\text { Market share of the major airline in a city-pair market ij for a given quarter } \mathrm{t} \\
\left(\mathrm{MKTDOMMS}_{\mathrm{ijt}}\right)\end{array}$ & $\begin{array}{l}.0103 * \\
(.0041)\end{array}$ & - \\
\hline $\begin{array}{l}\text { Market share squared of the major airline in a city-pair market ij for a given quar- } \\
\text { ter } t\left(M_{\text {KTDOMMSSQ }} \mathrm{ijt}\right)\end{array}$ & $\begin{array}{c}-8.0 \mathrm{e}-5^{*} \\
(3.2 \mathrm{e}-5)\end{array}$ & - \\
\hline $\begin{array}{l}\text { A dummy variable captured by } 1 \text { if there is gate control or slot control at either of } \\
\text { the two cities of a city-pair market ij and } 0 \text { if otherwise }\left(\text { BARRIER }_{\mathrm{ij}}\right)\end{array}$ & $\begin{array}{l}-.1058^{\text {n.s. }} \\
(.3059)\end{array}$ & $\begin{array}{l}.0960^{n} \cdot \mathrm{s} . \\
(.3788)\end{array}$ \\
\hline $\begin{array}{l}\text { Market share of the discount airline in a city-pair market ij for a given quarter } \mathrm{t} \\
(\text { DISCOUNTMS } \\
\text { ijt })\end{array}$ & - & $\begin{array}{l}5.889 \mathrm{e}-3^{*} \\
(1.96 \mathrm{e}-3)\end{array}$ \\
\hline $\begin{array}{l}\text { Market share squared of the discount airline in a city-pair market ij for a given } \\
\text { quarter } \mathrm{t} \text { (DISCOUNTMSSQ }{ }_{\mathrm{ijt}} \text { ) }\end{array}$ & - & $\begin{array}{l}-2.1 \mathrm{e}-4^{*} \\
(4.4 \mathrm{e}-5)\end{array}$ \\
\hline $\begin{array}{l}\text { The size of the discounter in terms of total number of passengers carried in all } \\
\text { markets (DISCOUNTSIZE } \text { f }_{t} \text { ) }\end{array}$ & $\begin{array}{l}5.622 \mathrm{e}-6^{*} \\
(8.495 \mathrm{e}-7)\end{array}$ & $\begin{array}{l}-6.15 \mathrm{e}-6^{*} \\
(1.398 \mathrm{e}-6)\end{array}$ \\
\hline Interaction 1 (MKTDOMMS × BARRIER) & $\begin{array}{l}.0012^{\text {n.s. }} \\
(.0049)\end{array}$ & $\begin{array}{l}-1.16 \mathrm{e}-3^{n} . \mathrm{s} \\
(6.022 \mathrm{e}-3)\end{array}$ \\
\hline Interaction 2 (DISCOUNTMS $\times$ BARRIER) & $\begin{array}{l}.0142^{\text {n.s. }} \\
(.0124)\end{array}$ & $\begin{array}{c}-1.374 \mathrm{e}-2^{\text {n.s. }} \\
(1.5779 \mathrm{e}-2)\end{array}$ \\
\hline Constant & $\begin{array}{c}-.3959 \\
(.1251)\end{array}$ & $\begin{array}{c}.2006 \\
(.0276)\end{array}$ \\
\hline
\end{tabular}

$* p<.01$.

Notes: n.s. = not significant.

found to be important. In particular, our conception of market power to include its domain, the countervailing power of rivals, and particular barriers to entry may be helpful. Furthermore, our analysis of the concentration and yield premiums in the hub markets across the top 50 airports is informative to empirical questions about market power. In addition, our analysis of a major airline's price response to the entry of discount airlines is informative. Finally, our simultaneous equation model provides insights into the DOT's profit-maximizing response standard.

Overall, our research demonstrates the utility of empirical examination that relies on industry data for informing questions related to predatory pricing and its assessment under the law. We hope that it provides new direction for other empirical studies so that a wealth of findings can accumu- late and more definitive answers to these questions may be obtained. In addition to academics, the primary beneficiaries of this research are likely to be parties that are responsible for developing, enforcing, and assessing competition and competition policy and laws in the marketplace and consumers, who ultimately will benefit from increased competition, lower prices, and more choices.

\section{Further Research}

An important direction for further research is to investigate predatory pricing in the wake of the recent technological developments and globalization. Several years after the landmark case against Microsoft, scholars are still divided over interpreting the economics of dynamic network indus- 
tries. Strict adherence to rules (e.g., below-cost pricing) may pose challenges in the case of industries (e.g., intellectual property) for which costs are extremely difficult to estimate. A more careful examination and factual inquiry into the Supreme Court elements of market power, predatory conduct, and recoupment is needed. Rather than relying on simplifying assumptions about the marketplace, scholars should attempt to examine these elements by applying considerations that are more representative of the context in which such conduct may occur. Our study of the airline industry offers one such examination to elaborate on the complex phenomenon of predatory pricing.

\section{Appendix: Some Highlights of the DOT (2001) Report}

The DOT (2001) report contends that the response of an incumbent network airline in terms of price cuts and capacity expansion, or other tactics that may appear economically rational only if the incumbents force the new entrant to exit the market, may warrant action by the DOT. However, no action is warranted if the new airline is not able to survive because of internal reasons, such as inefficiency or the inability to attract passengers because of ineffective marketing programs. Therefore, the role of the DOT is restricted to protecting competition, not the individual competitor. Furthermore, ample opportunity should be given to the incumbent network airline to show that its behavior was legitimate and not aimed at reducing competition.

The DOT (2001) also contends that it has authority that is comparable to that of the Federal Trade Commission to prohibit unfair methods of competition, even if they do not violate the Sherman or Clayton Act. Therefore, the DOT could institute a policy by which it would act under the authority provided by Section 411 in the case of a drastic slashing of fares and an increase in the capacity in monopolistic or oligopolistic markets. The DOT would base its decisions on how the competition operates in the airline industry and may not dismiss the possibility of action in cases in which the incumbent airline's fares appear to be above cost. The Court's observations in Brooke Group Ltd. v. Brown Williamson Tobacco Corp. (1993) do not prevent the DOT from beginning enforcement proceedings when the incumbent airline's behavior may be lawful under the Sherman Act. Furthermore, because the DOT cannot award damages and because Section 411 does not create a private right of action, the DOT's finding that an airline engaged in unfair methods of competition would not establish liability in a private suit under the Sherman Act. Thus, the DOT's authority under Section 411 is not likely to reduce legitimate competition.

In summary, preventive action by the DOT is likely to increase service to small and medium-sized communities. The enforcement action against unfair exclusionary practices will also increase competition in the local hub markets. Protecting competition is not the same as reregulating the airline industry. Firms in every unregulated industry are subject to laws that are designed to ensure the maintenance of competition, and the DOT's statute gives it authority similar to that of the Federal Trade Commission to prohibit unfair methods of competition.

\section{References}

Adams, Walter and J. Brock (1996), "Predation, Rationality, and Judicial Somnambulance," University of Cincinnati Law Review, 64 (3), 811-78.

American Bar Association (2002), Antitrust Law Developments: Section of Antitrust Law. Chicago: American Bar Association.

Areeda, Philip and Herbert Hovenkamp (2000), Antitrust Law: An Analysis of Principles and Their Applications. New York: Aspen Law and Business.

- and Donald Turner (1975), "Predatory Pricing and Related Practice Under Section 2 of the Sherman Act," Harvard Law Review, 88 (4), 720-32.

Bolton, P., J.F. Brodley, and M.H. Riordan (2000), "Predatory Pricing: Strategic Theory and Legal Policy," Georgetown Law Journal, 88 (August), 2239-41.

Borenstein, S. (1989), "Hubs and High Fares: Dominance and Market Power in the U.S. Airline Industry," Rand Journal of Economics, 20 (3), 344-65.

Bork, Robert H. (1978), The Antitrust Paradox. New York: Basic Books.

Brooke Group Ltd. v. Brown Williamson Tobacco Corp. (1993), 61 L.W. 4699.

Cargill Inc. v. Monfort of Colorado Inc. (1986), 479 U.S. 104.

Dekimpe, M.G., Dominique M. Hanssens, Vincent Nijs, and JanBenedict E.M. Steenkamp (2001), "Competitive Reactions: Intensity and Effectiveness," paper presented at Marketing Science Institute Conference on Competitive Responses, Boston (May 17-18).

Dowling, Grahame R. and Mark Uncles (1997), "Do Customer Loyalty Programs Really Work?" Sloan Management Review, 38 (4), 71-82.

Dresner, Martin and Michael Tretheway (1992), "Modeling and Testing the Effect of Market Structure on Price: The Case of International Air Transport," Journal of Transport, Economics and Policy, 26 (2), 171-84.

Edlin, Aaron S. (2002), "Stopping Above Cost Predatory Pricing," Yale Law Journal, 111 (January), 941-86.

Gellhorn, Ernest (1975), “An Introduction to Antitrust Economics," Duke Law Journal, (March), 1-43.

Gifford, Daniel (1994), "Predatory Pricing Analysis in the Supreme Court," Antitrust Bulletin, 39 (2), 431-83.

Grewal, D. and L.D. Compeau (1999), "Pricing and Public Policy," Journal of Public Policy \& Marketing, 18 (Spring), 3-10.

Guiltinan, Joseph P. and Gregory T. Gundlach (1996), "Aggressive and Predatory Pricing: A Framework for Analysis," Journal of Marketing, 60 (July), 87-102.

Hawker, Norman W. (1996), "Wal-Mart and the Divergence of State and Federal Predatory Pricing Law," Journal of Public Policy \& Marketing, 15 (Spring), 141-47.

Hemphill, C. Scott (2001), "The Role of Recoupment in Predatory Analysis," Stanford Law Review, 53 (July), 1581-1612.

Kahn, Alfred E. (2000), “Airline Competition: Clear Skies or Turbulence Ahead?" statement on Assertedly Predatory Airline Pricing Before the Subcommittee on Antitrust of the United States Senate Committee on the Judiciary, No. J-106-80, pp. $4-8$. 
Kate, A.T. and G. Neils (2002), "On the Rationality of Predatory Pricing: The Debate Between Chicago and Post-Chicago," The Antitrust Bulletin, 47 (Spring), 1-24.

Levine, M. (1991), “Airline Deregulation: A Perspective," Antitrust Law Journal, 60 (2), 687-94.

Liggett Group Inc. v. Brown \& Williamson Tobacco Corp. (1990), Civil No. C-84-617-D.

London, Martin, Norwood Robinson, and Michael L. Robinson (1989), "Defendant's Proposed Jury Instructions: Predation Requires at Least 28\% Market Share," Antitrust Law and Economics Review, 21 (4), 99-110.

Mansfield, Edwin (1982), Microeconomics Theory and Applications, 4th ed. New York: W.W. Norton and Company.

Matsushita Electric Industrial Company v. Zenith Radio Corporation (1986), 475 U.S. 574.

McCloskey, Donald N. (1985), The Applied Theory of Price, 2d ed. New York: Macmillan.

Molm, Linda D. (1990), "Structure, Actions and Outcome: The Dynamics of Power in Exchange Relations," American Sociological Review, 55 (3), 427-47.

Ordover, J. and R.D. Willig (1981), "An Economic Definition of Predation: Pricing and Product Innovation," Yale Law Journal, 91 (1), 8-54.

Oster, C.V., Jr., and J.S. Strong (2001), "Predatory Practices in the US Airline Industry," (January 15), (accessed July 18, 2006), [available at http://ostpxweb.dot.gov/aviation/domesticcompetition/predpractices.pdf].
Robinson-Patman Act (1936), 15 U.S.C.A Sec. 13.

Sherman Antitrust Act (1890), 15 U.S.C.A. Secs. 1-7.

Shores, David F. (1995), "Law, Facts and Market Realities in Antitrust Cases After Brooke and Kodak," Southern Methodist University Law Review, 48 (July-August), 1835-80.

Stigler, George (1966), The Theory of Price, 3d ed. New York: Macmillan.

Sullivan, Lawrence A. and W.A. Grimes (2000), The Law of Antitrust: An Integrated Handbook. St. Paul, MN: West Group.

Transportation Research Board (1999), Entry and Competition in the U.S. Airline Industry: Special Report 255. Washington, DC: National Academy Press, 40-44.

U.S. Department of Justice v. AMR Corporation (1999), $140 \mathrm{~F}$ Supp. 2d 1141.

U.S. DOT (2001), Enforcement Policy Regarding Unfair and Exclusionary Conduct in the Air Transportation Industry, Docket OST-98-3713 (January).

U.S. General Accounting Office (1996), "Airline Deregulation: Barriers to Entry Continue to Limit Competition in Several Key Domestic Markets," report to the Chairman, Committee on Commerce, Science and Transportation, U.S. Senate, (October).

U.S. v. E.I. DuPont de Nemours \& Co. (1956), 351 U.S. 377.

Wooldridge, J.M. (2002), Econometric Analysis of Cross-Section and Panel Data. Cambridge, MA: The MIT Press.

Zerbe, Richard O., Jr., and Michael T. Mumford (1996), "Does Predatory Pricing Exist?" Antitrust Bulletin, (Winter), 949-85. 
Copyright of Journal of Public Policy \& Marketing is the property of American Marketing Association and its content may not be copied or emailed to multiple sites or posted to a listserv without the copyright holder's express written permission. However, users may print, download, or email articles for individual use. 